Research Article

\title{
INVESTIGATING THE QUALITY OF COMMERCIAL BEEF CATTLE FEEDS AND FEED INGREDIENTS USED IN BANGLADESH
}

\author{
M.T. Kamal ${ }^{1}$, M.A. Hashem ${ }^{1 *}$, M. Al-Mamun ${ }^{2}$, M.M. Hossain ${ }^{1}$ \\ M.A. Razzaque ${ }^{3}$ and J.H. Ritu ${ }^{1}$ \\ ${ }^{1}$ Department of Animal Science, Bangladesh Agricultural University \\ Mymensingh-2202, Bangladesh. \\ ${ }^{2}$ Department of Animal Nutrition, Bangladesh Agricultural University \\ Mymensingh-2202, Bangladesh. \\ ${ }^{3}$ Desert Agriculture and Ecosystem Program, Kuwait Institute for Scientific Research \\ Safat 13109, Kuwait
}

\begin{abstract}
The study was undertaken to evaluate the quality of commercial beef cattle feed and feed ingredients which are available in Bangladesh. For this purpose, chemical analysis and in vitro digestibility (IVD) were estimated for nine commercial feeds and different feed ingredients which were collected from different regions. Chemical analysis of samples was carried out in triplicate for dry matter (DM), crude protein (CP), crude fiber (CF), ether extract (EE), ash, acid detergent fiber (ADF) and neutral detergent fiber (NDF) content. Metabolizable energy (ME) was calculated mathematically for feed samples by using standard formula. The analysis revealed the difference between the manufacturer's claim and actual analyzed value. In commercial feeds DM content ranged from 90-92\%. While CP content of commercial feeds was either lower or higher than the written value of feed industries. In Provita feed CP content $(20.72 \%)$ was higher and Care feed had much lower CP content (7.54\%) than written value. In vitro digestibility of DM in feed ingredients varied from 18.27 in straw to $75.77 \%$ in soybean meal. The fiber component (NDF and ADF) was negatively correlated with IVDMD and CP was positively correlated with IVDMD because fiber rich components were less digestible than the non-fibrous component (protein). Analysis of commercial feed samples revealed that the values claimed by the manufacturers are quite different from the actual analyzed values. This is a matter of concern and needs to be checked through better quality control measures by systematic feed analysis and ensure that manufacturers declare the true composition of the marketed feeds.
\end{abstract}

Keyword: Beef cattle feed, Quality, Chemical analysis, In vitro digestibility (IVD)

* Corresponding author: hashem_as@bau.edu.bd

Received: 27.04.2020

Accepted: 10.06 .2020 


\section{INTRODUCTION}

In Bangladesh, livestock sector is one of the major components of agricultural activities and plays a crucial role in economic development by ensuring food security and stimulating the growth of a number of subsidiary industries (Goutam et al., 2017). Approximately $64 \%$ of the livestock farmers practiced fattening round the year and rest of the farmers followed fattening for period of 3 months; before Eid-ulAdha (Kamal et al., 2019). Malpractice of feed adulteration and use of waste contaminated feeds are common practices in Bangladesh. Feed shortage is the main reason for low productivity of livestock in Bangladesh (Rahman et al., 1998; Baset et al., 2003; Jahan et al., 2018) and at the same time farmers are not able to formulate a balanced ration leading to loss of productivity. To fulfill the requirement of farmer for concentrate feed, commercial feed industries are marketing the branded feeds to cater the market demand. Ideally the role of these industries should be to provide high quality livestock feeds to enhance production by meeting the nutrient requirements of livestock in different stages of growth or production. The recognized feed mills (ACI Godrej, Lal Teer, Care, Gain, Index, Soudia feed, Provita feed etc.) as a marketing strategy display various essential nutrients percentage on the feed package to attract/deceive the farmers. So, a question arises whether the animal feed industries maintain the composition accurately in the feed as mentioned in the package and the feed is free from harmful objects or they attempt to mislead the consumer. Misleading information in the nutritional profile of feed provided by the suppliers erodes the consumer confidence and loss of productivity.

The farmers are faced with multiple challenges regarding the poor and inconsistent quality of commercial feeds, limited capital, and insufficient knowledge of nutritive value of commercial feeds (Laswai and Nandonde, 2013). Commercial feed producers tend to sell their feed by exaggerating the nutritional profile of the feed leading to poor production performance of livestock and loss to the farmers. This practice challenges the reliability of commercial feed quality besides effecting the safety of feed in cattle.

It is beyond the scope of this research to provide a detailed explanation of nutritional value of manufactured cattle feed and feed ingredients, especially because this is a very specific subject area. Current research will lead to better understanding of the chemical composition of the commercial feeds for beef cattle. Findings of the present study will help the farmers of Bangladesh in understanding the quality of the purchased commercial feeds leading to better feeding. An ideal combination of ingredients in compounded feed ensures rational use of available resources while meeting the nutritional requirements of the animal. So, the approach of compounded feed can be an economic attempt for better feed production as well as increasing productivity and nutritional status of livestock. The ultimate goal of feed analysis is to assess the quality of beef cattle feed through nutrient composition. 


\section{MATERIALS AND METHODS}

\section{Experimental site}

The experiment was conducted at Department of Animal Science laboratory and Animal Nutrition Laboratory, BAU, Mymensingh.

\section{Collection of samples}

Nine (9) manufactured beef cattle feed samples ( 8 concentrate and a total mixed ration) and eleven (11) feed ingredients were collected from different commercial feed mills and feed dealers of Bangladesh. It is important that samples are true representative of the whole that reflects of what livestock farmers are buying. Oven dried samples were ground in a grinding machine (Cyclotec sample mill Tecator, Sweden) by using $1.0 \mathrm{~mm}$ sieve for chemical analysis. The ground samples in three replicates of around $250 \mathrm{~g}$ each were kept in air tight zip lock bag for further chemical analysis.

Feed quality (nutritive value) analyses: The samples were analyzed for proximate analysis such as DM (Dry matter), CP (Crude protein) and ash following the method of AOAC (2005). All determination was done in triplicate and the mean value was reported. Acid detergent fiber (ADF) and Neutral detergent fiber (NDF) were determined by following the procedures of Goering and Van Soest (1970).

\section{In-vitro study}

An in-vitro study was conducted to determine the organic matter digestibility (OMD) and metabolizable energy (ME) contents of feedstuffs according to the methods of Menke et al. (1979) and Menke and Steingass (1988).

\section{Calculation of organic matter digestibility and ME contents}

The organic matter digestibility (OMD\%) and metabolizable energy (ME, MJ/kg $\mathrm{DM})$ contents were calculated from the gas volume $(\mathrm{Gv})$ and Crude protein value (CP\%) using the following equations proposed by Menke and Steingass (1988).

\section{Roughages samples:}

OMD $(\%)=9.00+0.9991 \mathrm{Gp}+0.0595 \mathrm{CP}+0.0181 \mathrm{TA}$

$\mathrm{ME}(\mathrm{MJ} / \mathrm{kg} \mathrm{DM})=2.20+0.136 * \mathrm{Gp}+0.0574 * \mathrm{CP}$

\section{Concentrate samples:}

IVOMD $(\%)=9.00+0.9991 \mathrm{Gp}+0.0595 \mathrm{CP}+0.0181 \mathrm{TA}$

$\mathrm{ME}=1.06+0.1570 \mathrm{Gp}+0.0054 \mathrm{CP}+0.0139 \mathrm{EE}-0.0054 \mathrm{TA}$

Where,

$\mathrm{OMD}=$ Organic matter digestibility

$\mathrm{ME}=$ Metabolizable energy $(\mathrm{MJ} / \mathrm{Kg} \mathrm{DM})$

$\mathrm{Gp}=24 \mathrm{~h}$ gas production $(\mathrm{ml} / 200 \mathrm{mgDM})$ 
$\mathrm{CP}=$ Crude protein $(\%)$

$\mathrm{TA}=$ Total ash content $(\%)$

$\mathrm{EE}=$ Ether extract $(\%)$

\section{Statistical analysis}

The collected data of proximate analysis and gas production were statistically analyzed using "Analysis of Variance" technique with the help of computer program, SAS (Version 9.1.3).

\section{RESULTS AND DISCUSSION}

\section{Chemical analysis of manufactured feed}

The proximate analysis of nine (9) commercial beef cattle feeds are shown in table 1. The DM (\%) content ranged from 90 to $92 \%$. It was observed that the DM content of feeds was almost same. Mean ash content ranged from 8.68 to $22.08 \%$. Mean Ash contents of Gain feed (22.08\%) and Saudia feed (19.56\%) was higher than other feed. Higher ash content may be due to the bone content of feeds of animal origin and soil contamination during harvest of feeds of plant origin. Normally beef cattle feeds contain 14-18\%crude protein (NRC, 2000). Crude protein content in beef cattle feed samples were found to vary widely. In Provita feed CP content $(20.72 \%)$ was high while in Care feed CP content $(7.54 \%)$ was much lower than manufacturers claimed value and lower than the standard protein requirements of beef cattle. CP includes both true protein and non-protein nitrogen which can be used most efficiently by ruminant animals. Some protein fractions are more digestible then others, but in general the higher the protein level, the more digestible is the feed. Mean crude fiber (CF) content ranged from 4.01 to $10.11 \%$. Higher crude fiber content observed in Gain feed $(10.11 \%)$ is not favorable. Crude fiber is poorly digested component of a feed and is made up of cellulose, hemicelluloses and lignin. Mean fat value of beef cattle feeds ranged from 2.25 to $4.67 \%$, which is within the normal range. Higher fat content is susceptible to rancidity, leading to off flavor, low palatability and toxic effects. Mean ADF value of cattle feed was within the favorable range of 17.66 to $22.85 \%$. ADF is the least digestible portion of fiber which affects the feeds digestibility negatively. ADF content is inversely related to the digestibility. Mean NDF value ranged from 30.42 to $33.11 \%$, whereas the standard NDF value of beef cattle feed is $35 \%$. NDF is a major parameter that should be controlled in cattle feed formulation as it controls the feed intake of ruminants. Across feeds ash and fiber content had a significant variation $(\mathrm{P}<0.05)$. CP content was lower in Care and Saudia feed than MV value (table 1). Analyzed CP content of Provita feed was higher than the manufactured value. But, EE content of feeds was lower than the manufactured value which is good for animal health. A graphical presentation is shown in fig. 1. 


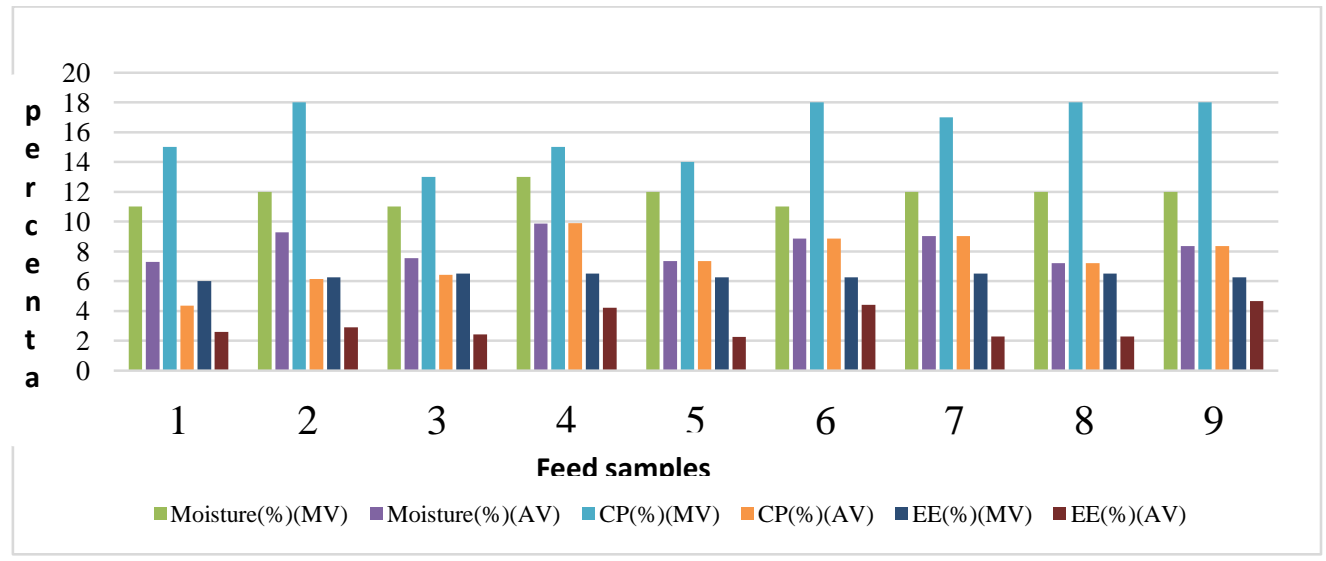

Figure 1. Difference between analytical value (AV) and manufactured value (MV) of commercial feed

\section{Chemical analysis and In-vitro digestibility of feed ingredients:}

The proximate composition and invitro digestibility of feed ingredients was shown in Table 2.

Sesame oil cake is a valuable source of protein fed to ruminant livestock and poultry (Hansen, 2011; Oplinger et al., 1997). DM, crude protein, crude fiber and ash (\%) range of analyzed sesame oil cake were $91-93 \%, 14-15 \%, 0.55-0.80 \%$ and $11.34-$ $13 \%$, respectively. Wheat bran is the concentrate ruminant feed and widely used in Bangladesh in every region. Maximum recommended inclusion rates are $10 \%$ in calves, $20 \%$ in dairy cows and $25 \%$ in beef cattle (Ewing, 1997). In Bangladesh, it is used up to $50 \%$ of the total diet. It has a slightly laxative effect, partly because the bran fiber is moderately digested (Gohl, 1982). Wheat bran contains protein (12\%), fat $(0.5 \%)$ and minerals $(2 \%)$ (Slavin, 2003). Analyzed results of wheat bran indicated that it was low in protein (7-9\%), 90-92\% DM and 2-2.50\% fat.

Maize is the main raw materials for poultry which is used approximately 50 to $60 \%$ of the total ration. Maize is also used in cattle feed formulation and is grown mainly in the northern part of Bangladesh. Mojisola (2005) reported that maize grains contained $8.96 \%$ crude protein, $4.09 \%$ crude fiber, $1.33 \%$ ash, $1.48 \%$ crude fiber and $7.15 \%$ moisture. Analyzed results for maize samples had 88-90\% DM, 5-6\% CP, 4$5 \% \mathrm{CF}$ and 2-2.50\% ash. Lower crude protein (5-6) found in maize may be due to its immature grains which contain low protein. Yadav (2002) reported 4.10-12.98\% CP, 4.98-5.45\% CF and 1.18-1.50\% ash in maize grains. Sharma (2013) reported that mustard Cake contained $91.42 \%$ dry matter (DM), 30.12\% crude protein (CP), 9.29\% ether extract (EE). However, analyzed MOC samples revealed lower crude protein (16\% CP) due to soil contamination and EE (3 -3.5\%) while DM (90-91\%) was found to be comparable. 
Table 1. Analytical value (AV) of proximate composition of commercial feeds and comparative study with the manufactured value (MV) written in bag

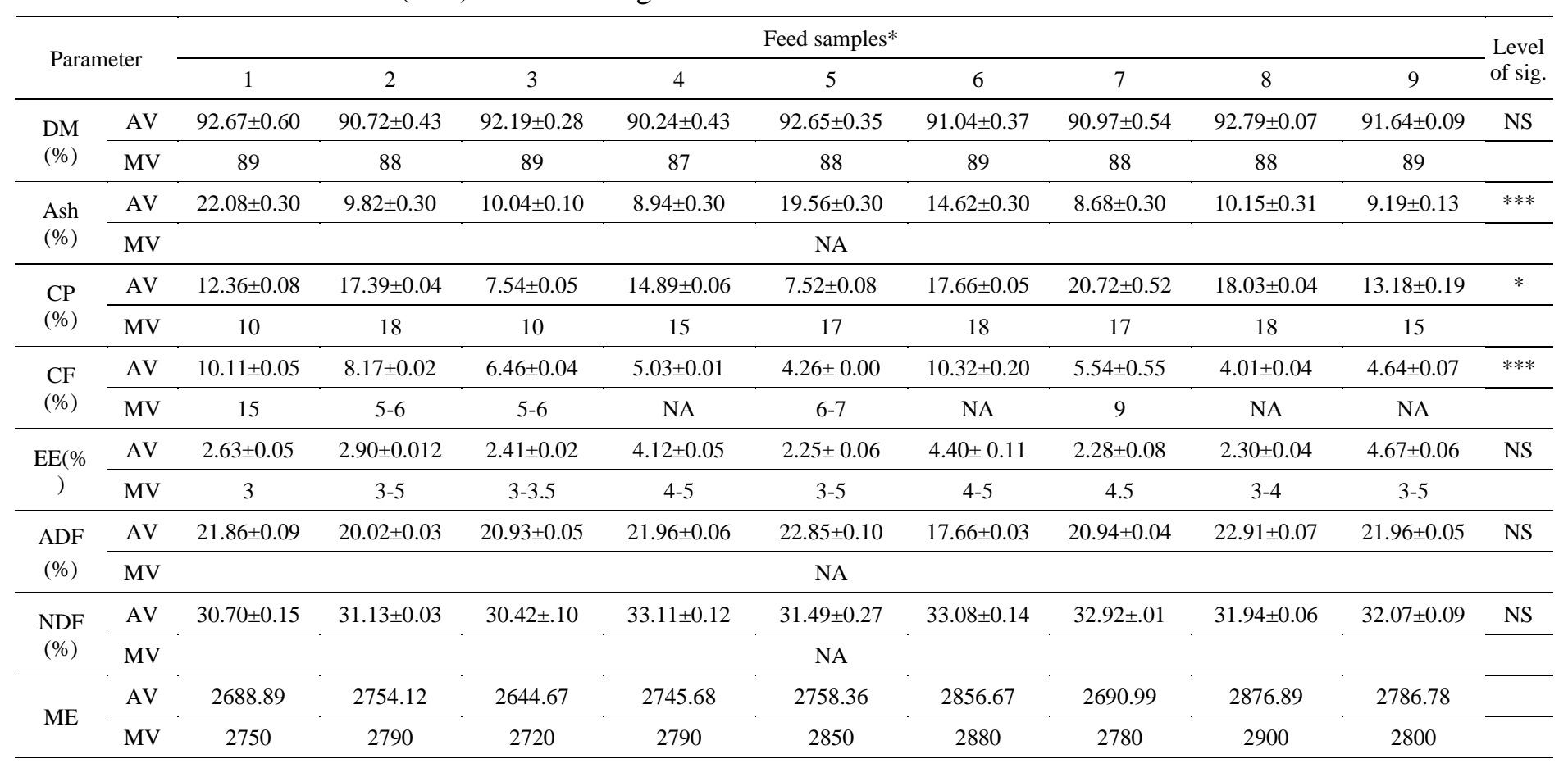

Note: Feed samples* 1= Gain feed, 2=ACI, 3=Care feed, 4=Teer feed, 5= Saudia feed, 6=Fresh feed, 7=Provita feed, 8=Index, 9=Total Mixed Ration (TMR), MV= Manufacturer's Value (Company supplying bag value); $\mathrm{AV}=$ Analytical Value (laboratory test result); $\mathrm{CP}=\mathrm{Crude} \mathrm{Protein} ; \mathrm{CF}=\mathrm{Crude}$ Fiber; EE= Ether Extract; and ME= Metabolizable energy $(\mathrm{Kcal} / \mathrm{kg})$. 
Table 2. Chemical analysis and in-vitro digestibility of feed ingredients

\begin{tabular}{lcccccccc}
\hline \multicolumn{1}{c}{ Parameter } & DM $(\%)$ & Ash $(\%)$ & CP $(\%)$ & CF $(\%)$ & EE $(\%)$ & ADF $(\%)$ & $\begin{array}{c}\text { NDF }(\%) \\
\text { IVDMD } \\
(\%)\end{array}$ \\
\hline Sesame cake & $91.87 \pm 0.11$ & $11.89 \pm 0.02$ & $14.87 \pm 0.11$ & $0.64 \pm .06$ & $8.89 \pm .06$ & $18.04 \pm 0.07$ & $24.49 \pm 0.36$ & $60.28 \pm 0.04$ \\
Wheat bran & $90.85 \pm 0.36$ & $4.35 \pm 0.08$ & $7.12 \pm 0.03$ & $0.40 \pm 0.029$ & $2.43 \pm 0.10$ & $13.91 \pm 0.06$ & $46.98 \pm 0.11$ & $68.56 \pm 0.04$ \\
Gram bran & $90.19 \pm 0.56$ & $4.17 \pm 0.40$ & $5.13 \pm 0.15$ & $24.26 \pm 0.17$ & $1.48 \pm 0.07$ & $18.11 \pm 0.04$ & $23.05 \pm 0.09$ & $50.25 \pm .0 .04$ \\
Maize & $88.90 \pm 0.58$ & $2.91 \pm 0.11$ & $4.44 \pm 0.12$ & $4.67 \pm 0.01$ & $3.14 \pm 0.24$ & $9.05 \pm 0.06$ & $25.10 \pm 0.06$ & $70.30 \pm 0.04$ \\
Mustard oil cake & $90.91 \pm 0.47$ & $10.26 \pm 0.07$ & $16.07 \pm 0.04$ & $3.18 \pm 0.10$ & $1.82 \pm 0.09$ & $17.19 \pm 0.10$ & $23.00 \pm 0.12$ & $65.76 \pm 0.30$ \\
Black gram hull & $87.53 \pm 0.77$ & $6.80 \pm 0.45$ & $7.84 \pm 0.06$ & $4.94 \pm 0.03$ & $2.36 \pm 0.38$ & $17.25 \pm 0.04$ & $24.17 \pm 0.14$ & $37.40 \pm 0.10$ \\
De-oiled rice bran & $91.74 \pm 0.00$ & $20.09 \pm 0.03$ & $4.61 \pm 0.05$ & $21.92 \pm 0.04$ & $2.07 \pm 0.35$ & $17.29 \pm 0.08$ & $46.93 \pm 0.25$ & $59.87 \pm 0.99$ \\
Rapeseed meal & $90.87 \pm 0.07$ & $7.06 \pm 0.05$ & $34.72 \pm 0.07$ & $9.08 \pm 0.10$ & $1.12 \pm 0.10$ & $9.93 \pm 0.10$ & $19.45 \pm 0.06$ & $70.64 \pm 0.89$ \\
Soybean meal & $89.58 \pm 0.24$ & $7.89 \pm 0.02$ & $39.76 \pm 0.03$ & $2.25 \pm 0.03$ & $1.81 \pm 0.02$ & $8.30 \pm 0.18$ & $12.14 \pm 0.09$ & $75.77 \pm 0.67$ \\
Rice Polish & $89.25 \pm 0.19$ & $4.95 \pm 0.04$ & $8.60 \pm 0.10$ & $4.71 \pm 0.02$ & $0.87 \pm 0.01$ & $21.35 \pm 0.24$ & $38.34 \pm 0.96$ & $61.78 \pm 0.03$ \\
Straw & $93.98 \pm 0.12$ & $11.95 \pm 0.03$ & $2.66 \pm 0.04$ & $32.89 \pm 0.06$ & $1.71 \pm 0.04$ & $55.40 \pm 1.21$ & $71.04 \pm 0.66$ & $18.27 \pm 0.02$ \\
\hline
\end{tabular}


Rapeseed meal (RSM) is a protein rich feed which is widely used in different feed mills of Bangladesh especially in fish and dairy feed. RSM contained90-91\% DM and $1-2 \%$ fat. Mean crude protein (\%) content of RSM samples obtained was $34.92 \pm$ 3.33 and was lower than those reported by many other authors (Blair et al., 1986; Verma and Banday, 1997). Soybean meal is the by-product of soybean which is produced after extraction of oil. In Bangladesh there are two commercial oil companies namely City and Fresh producing soybean meal. It is a good source of protein which contains less than 1\% fat. Analyzed Soybean meal contained 88-89\% dry matter (DM), 39-40\% crude protein (CP) and 1-2\% ether extract (EE).

Rice polish is a by-product of rice which contains $89-90 \%$ dry matter (DM), 8-9\% crude protein (CP) and $0.7-0.8 \%$ fat (EE). Rice polish is the most common feed ingredient and widely used in poultry, cattle and fish feed. It is a good source of protein (13.2 to $17.1 \%)$, carbohydrate $(16.1 \%)$, fiber $(9.5$ to $13.2 \%)$, vitamins and minerals (Vargasgonzalez, 1995; Ambashankar and Chandrasekaran, 1998). Straw is amain by-product of rice and found all over Bangladesh. Straws are usually produced after harvesting the grains and can be grazed by livestock (Suttie, 2000). Straw contains DM (93-94\%), protein (2-5\%), CF (32\%) and ADF (55-56\%) with low digestibility. Many attempts have been done to increase the digestibility of straw by urea and molasses treatment (Sarnklong et al., 2010).

Feed ingredients which are in low digestibility tend to contain high fiber (ADF and $\mathrm{NDF}$ is high). The in vitro gas production system helps to better quantify nutrient utilization and its accuracy in describing digestibility in animals had been validated in numerous experiments (Taphizadeh et al., 2008). It was also found that type of feed and their nutritional quality enhance or reduce the $\mathrm{CH}_{4}$ gas production. According to this principle, some researchers formulate eco-friendly rations with low $\mathrm{CH}_{4}$ producing feed ingredients (Kim et al., 2012; Rahman et al., 2013).

\section{Relationship between chemical components with IVDMD}

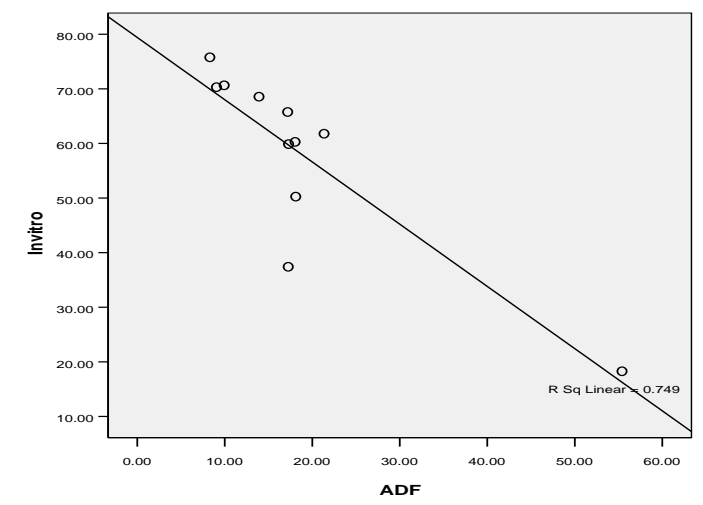

Figure 2. Relationship between ADF and In vitro dry matter digestibility (IVDMD) of feed ingredients 
There were significant negative correlations between neutral detergent fiber (NDF) and acid detergent fiber (ADF) with in vitro dry matter digestibility (IVDMD) (Fig. 2 and 3), while significant positive correlation was observed for crude protein $(\mathrm{CP}, \mathrm{r}=$ 0.59) (Fig.4).

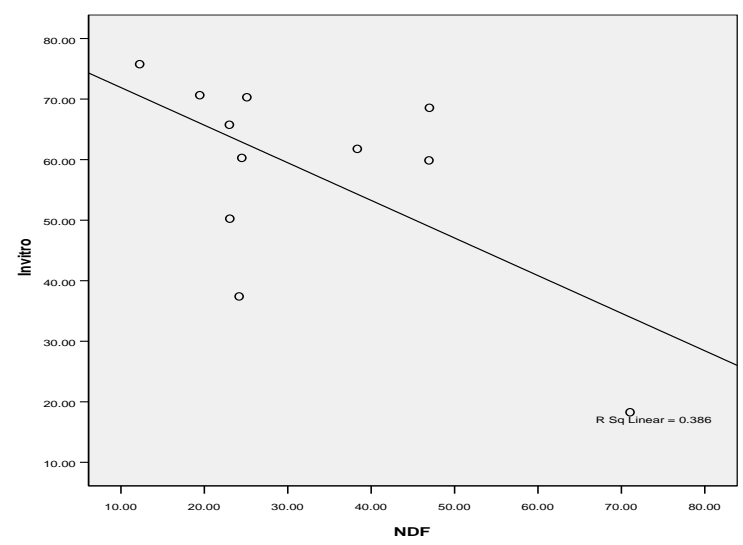

Figure 3. Relationship between NDF and in vitro dry matter digestibility (IVDMD) of feed ingredients

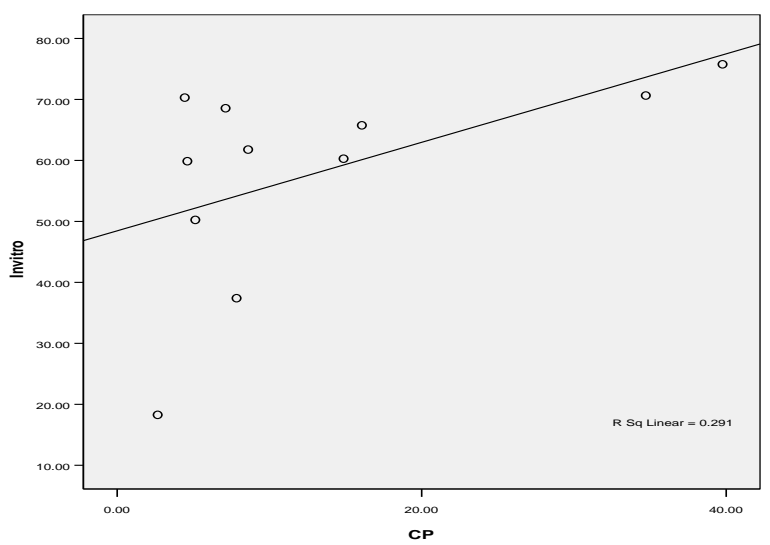

Figure 4. Relationship between $\mathrm{CP}$ content and In vitro dry matter digestibility (IVDMD) of feed ingredients

The fiber component (NDF and ADF) was negatively correlated with IVDMD because those components were less digestible than the non-fibrous component (protein). 


\section{CONCLUSIONS}

In the commercial feed, analyzed CP level was lower than the manufacturer's claimed value. It was found that the feed ingredients of the local market were not of good quality and this affected the quality of finished feeds. In vitro digestibility of the feeds and feed ingredients varied with their fiber content. Feeds which were high in fiber were low in digestibility. There is a large amount of variability in the feed constituents of compound feeds. This could be due to the use of low-quality feed stuffs due to lack of strict quality control measures. So, there is a need for better quality standards for feed ingredients and compound feeds through analysis. There is a need for creating awareness among the feed compounders and consumers regarding maintaining the feed quality and its benefits in creating the trust between the compounders and farmers leading to better livestock productivity.

\section{ACKNOWLEDGEMENT}

The investigation was supported by 'National Science and Technology (NST) Fellowship', awarded by the Ministry of Science and Technology (MoST), Government of Bangladesh and IFAEL.

\section{REFERENCES}

Ambashankar, K. and Chandrasekaran, D. (1998). Chemical composition and metabolizable energy value of rice waste for chicken. The Indian Veterinary Journal, 75: 475-476.

AOAC. (2005). Official Methods of Analysis of international 18th Ed., AOAC International, Gaithersburg, MD, USA, Official Method 2005.08.

Baset, M.A., Rahman, M.M., Islam, M.S., Ara, A. and Kabir, A.S.M. (2003). Beef cattle production in Bangladesh- A Review. Online Journal of Biological Sciences, 3(1): 8-25.

Blair, R., Misir, R., Bell, J.M. and Clandinin, D.R. (1986). The chemical composition and nutritional value for chicken of meal from recent cultivars of Canola. Canadian Journal of Animal Science, 66: 821-825.

Ewing, (1997). The Feeds Directory Vol 1. Commodity Products. Context Publications, Leicestershire, England.

Goering, H.K. and Van Soest, P.J. (1970). Forage fibre analyses (apparatus, reagents, procedures, and some applications). Agriculture Handbook No. 379, Agricultural Research Service, USDA, Washington, DC, USA, Pp. 20.

Gohl, B. (1982). Les aliments du bétail sous les tropiques. FAO, Division de Production et Santé Animale, Roma, Italy.

Goutam, K.K., Mohammad, A., Mosammat, S.A., Mohammad, S.K., Md MI, Gouri, M., Dipa, I., Liton, C.M. and Huque, A. (2017). Metal contamination of commercial fish feed and quality aspects of farmed tilapia (Oreochromis niloticus) in Bangladesh. Bioresearch Communications, 3(1): 345-353.

Hansen, R. (2011). Sesame. AgMRC, Iowa State University, USA. 
Jahan, R., Amin, M.R, Sarker, N.R. and Kamal, M.T. (2018). Feeding effects of total mixed ration on rumen metabolic profile in Cattle. Bangladesh Journal of Animal Science, 47(1): 35-39.

Kamal, M.T., Hashem, M.A., Al-Mamun, M., Hossain, M.M. and Razzaque, M.A. (2019). Study of cattle fattening system in selected region of Bangladesh. SAARC Journal of Agriculture, 17(1): 105-118.

Kim, M.J., Lee, J.S., Kumar, S., Rahman, M.M., Shin, J.S. and Ra, C.S. (2012). Indirect estimation of $\mathrm{CH}_{4}$ from livestock feeds through TOCs evaluation. Asian Australasian Journal of Animal Sciences, 25: 496-501.

Laswai, G. and Nandone, S. (2013). Report on Participatory Rural Appraisal to inform the three projects of More Milk IT, Safe Food Fair Food and Milk IT project in Morogoro and Tanga. ILRI, Nairobi.

Menke, K.H. and Steingass, H. (1988). Estimation of the energetic feed value obtained from chemical analysis and in vitro gas production using rumen fluid. Animal Research and Development, 28: 7-55.

Menke, K., Raab, L., Salewski, A., Steingass, H., Fritz, D. and Schneider, W. (1979). The estimation of the digestibility and metabolizable energy content of ruminant feeding stuffs from the gas production when they are incubated with rumen liquor in vitro. The Journal of Agricultural Science, 93(1): 217-222.

Mojisola O.E., Lateef, O.S. and Abiodun, I. (2005). Evaluation of maize- soyabean flour blends for sour maize bread production in Nigeria. African Journal of Biotechnology, 4(9): $911-918$.

NRC. (2000). Nutrient Requirements of Beef Cattle (7th Edition). National Academy Press, Washington, D.C.

Oplinger, E.S., Oelke, E.A., Doll, J.D., Bundy, L.G. and Schuler, R.T. (1997). Sesame. In: Alternative Field Crops Manual, University of Wisconsin-Extension, Cooperative Extension.

Rahman, M.M., Salleh, M.A.M., Sultana, N., Kim, M.J. and Ra, C.S. (2013). Estimation of total VFA from TOCs assessment through in vitro fermentation of livestock feeds. African Journal of Microbiology Research, 7: 1378-1384.

Rahman, M.M., Akther, S. and Hossain, M.M. (1998). The availability of the livestock feeds and feeding practices followed by the farmers of some areas of Mymensingh District. Bangladesh Journal of Animal Science, 27(1-2): 119-126.

Sarnklong, C., Cone, J.W., Pellikaan, W. and Hendriks, W.H. (2010). Utilization of rice straw and different treatments to improve its feed value for ruminants: A review. AsianAustralasian Journal of Animal Science, 23(5): 680 - 692.

Sharma, N.K. (2013). Chemical composition of oilseed cakes and de-oiled cakes in Nepal. Online Journal of Animal and Feed Research, 3(1): 74-76.

Slavin, J. (2003). Why whole grains are protective: biological mechanisms. Processing Nutrition Society, 62: 129-134.

Suttie, J.M. (2000). Hay and straw conservation for small-scale farming and pastoral conditions. FAO Plant Production and Protection Series No. 29, FAO, Rome. 
Taphizadeh, A., Palangi, A. and Safamehr, A. (2008). Determining nutritive value of Alfalfa cuts using in situ and gas production techniques. Journal of Animal and Veterinary Science, 3(3): 85-90.

Vargasgonzalez, E. (1995). The nutritive value of rice by-products in Costa Rica. Chemical composition, availability and use. Tropical Animal Nutrition, 2: 31-50.

Verma, S.V.S. and Banday, M.T. (1997). Rapeseed meal in poultry feeding: Future prospects. Poultry Punch, 13(11): 27-31.

Yadav, S.S. and Yadav, R.P. (2002). Studies on some quality traits of maize (Zea mays L.) genotypes. In: Adv. Maize Production Technology and Quality Improvement vt. Proc. Proceedings of National Seminar on Science- Industry Interface on Maize Production, Processing and Utilization, HPKV, Palampur, Nov 3-4, 2000. Pp. 181- 183. 